\title{
Fibroblastic osteosarcoma in a white-eared opossum (Didelphis albiventris) $^{1}$
}

\author{
Raqueli T. França ${ }^{2 *}$ (D) Érica T. Schulz ${ }^{2}$, Eduardo C. Oliveira ${ }^{3}$, \\ Wanderley W. Damarem ${ }^{3}$, Claudia Giordani ${ }^{3}$, Juliana A. Pletsch ${ }^{3}$ \\ and Luciana Sonne ${ }^{4}$ (D)
}

\begin{abstract}
França R.T., Schulz É.T., Oliveira E.C., Damarem W.W., Giordani C., Pletsch J.A. \& Sonne L. 2020. Fibroblastic osteosarcoma in a white-eared opossum (Didelphis albiventris). Pesquisa Veterinária Brasileira 40(7):559-563 Faculdade de Veterinária, Universidade Federal de Pelotas, Av. Eliseu Maciel s/n, Capão do Leão, RS 96160-000, Brazil. E-mail: raquelifranca@gmail.com

Osteosarcoma is characterized by the production of osteoid or woven bone, using neoplastic osteoblasts. It is the most common primary bone neoplasm in canines and humans. This neoplasm was previously reported in all vertebrate classes, including a wide variety of mammals. However, there is no case report describing this neoplasm in Didelphis albiventris. Therefore, the objective of this manuscript is to describe the clinical-pathological aspects of fibroblastic osteosarcoma in D. albiventris. A wild adult male white-eared opossum (D. albiventris) arrived at the zoological park of the "Universidade de Caxias do Sul" with a swollen left thoracic limb. After a general clinical examination, the animal was transferred to the Veterinary Clinic of "Universidade de Caxias do Sul" for radiographic examination of the left thoracic limb and thorax. Additionally, some material was collected through fine needle aspiration (FNA) for cytologic evaluation. The radiographic findings and cytologic evaluation indicated osteosarcoma. The animal was euthanized due to severe clinical conditions and guarded prognosis. During necropsy, macroscopic analysis of the viscera was performed, fragments of various organs were collected and fixed in $10 \%$ neutral buffered formalin. All fragments were processed following routine histological techniques. The histopathological evaluation confirmed osteosarcoma, which was classified as a fibroblastic subtype. Case reports are crucial for the knowledge of incidence, prevalence, and behavior of the current mentioned disease, as well as other diseases, in species with such limited information. In order to obtain a decisive diagnosis, a few different examination methods were associated. Although the observations presented are based on a single case, this neoplasm had a similar clinical presentation to that described in other species.
\end{abstract}

INDEX TERMS: Fibroblastic osteosarcoma, white-eared opossum, Didelphis albiventris, radiology, cytology, osteosarcoma, wildlife animals.

RESUMO-- [Osteossarcoma fibroblástico em gambá-deorelha-branca (Didelphis albiventris).] 0 osteossarcoma é caracterizado pela produção de osteoide ou osso imaturo, por osteoblastos neoplásicos. É a neoplasia óssea primária

\footnotetext{
${ }^{1}$ Received on March 8, 2020.

Accepted for publication on April 13, 2020.

${ }^{2}$ Faculdade de Veterinária, Universidade Federal de Pelotas (UFPel), Av. Eliseu Maciel s/n, Capão do Leão, RS 96160-000, Brazil. *Corresponding author: raquelifranca@gmail.com

${ }^{3}$ Curso de Medicina Veterinária, Universidade de Caxias do Sul (UCS), Rua Francisco Getúlio Vargas 1130, Petrópolis, Caxias do Sul, RS 95070-560, Brazil.

${ }^{4}$ Setor de Patologia Veterinária, Universidade Federal do Rio Grande do Sul (UFRGS), Av. Bento Gonçalves 9090, prédio 42505, Agronomia, Porto Alegre, RS 91540-000, Brazil.
}

mais comum em caninos e humanos. Essa neoplasia já foi relatada em todas as classes de vertebrados, incluindo uma grande variedade de mamíferos. Não havendo descrição dessa neoplasia até o momento em Didelphis albiventris. 0 objetivo deste trabalho é descrever aspectos clínico-patológicos de um caso de osteossarcoma fibroblástico em $D$. albiventris. Chegou para atendimento no Zoológico da Universidade de Caxias do Sul um gambá-de-orelha-branca (D. albiventris), macho, adulto, de vida livre com aumento de volume no membro torácico esquerdo. Após avaliação clínica geral, o animal foi encaminhado para a Clínica Veterinária da Universidade de Caxias do Sul para realização de radiografia do membro torácico esquerdo e de tórax, sendo também realizada coleta de material 
por punção aspirativa por agulha fina (PAAF) para avaliação citológica. Os achados radiográficos e da avaliação citológica foram sugestivos de osteossarcoma. Devido ao estado clínico grave e prognóstico reservado optou-se pela eutanásia. Durante a necropsia realizou-se a análise macroscópica das vísceras, foram coletados fragmentos de diversos órgãos, fixados em formalina $10 \%$, processados pelas técnicas histológicas de rotina. Na avaliação histopatológica confirmou-se a suspeita de osteossarcoma sendo classificado no subtipo fibroblástico. A descrição de relatos é fundamental para conhecimento da incidência, prevalência e comportamento desta e de outras doenças em espécies que as informações são limitadas. A associação de diferentes métodos de exames foram necessários para a obtenção de um diagnóstico definitivo. Embora as observações apresentadas se baseiem em um caso único, esta neoplasia possuiu apresentação clínica semelhante a descrita em outras espécies.

TERMOS DE INDEXAÇ̃̃O: Osteossarcoma fibroblástico, gambá-deorelha-branca, Didelphis albiventris, radiologia, citologia, osteosarcoma, animais selvagens.

\section{INTRODUCTION}

Opossums are marsupials belonging to the family Didelphidae, order Didelphimorphia, infraclass Methateria, subclass Theria, and class Mammalia. Distribution varies widely across South America, while presenting nocturnal habits, having omnivorous feed preferences, being opportunistic, and living in peri-urban regions. Altogether, there are 65 species of the family Didelphidae described, classified within 17 different genera (Costa et al. 2015). In Brazil, three species are found: Didelphis marsupialis, Didelphis aurita, and Didelphis albiventris (Abreu 2013).

These animals are affected by infectious and neoplastic disorders (Baker et al. 1995). There is limited up-to-date scientific literature about neoplasm in opossums, being restricted to cases in the Didelphis virginiana species (Pope \& Donnell 2017). There is also a scarcity of information about the incidence, prevalence, predisponent factors, and behavior of neoplasms in wild animals (Johnson et al. 2014, Madsen et al. 2017).

Osteosarcoma is characterized by the production of osteoid or woven bone, using neoplastic osteoblasts, presenting itself into three different subtypes: osteoblastic, chondroblastic, and fibroblastic (Thompson \& Dittmer 2017). This neoplasm was reported in all classes of vertebrate animals, including a wide variety of mammals such as felines (Heldmann et al. 2000), canines (Anfinsen et al. 2011), equines (Bush et al. 2007), bovines (Nagamine et al. 2014), four-toed hedgehogs (Atelerix albiventris) (Reyes-Matute et al. 2017), baboons (Mezzles et al. 2015), guinea pigs (Cavia porcellus) (Cojean et al. 2018), rabbits (Ishikawa et al. 2012), birds (Anthropoides paradiseus) (Churgin et al. 2013), and reptiles (Aspidites ramsayi) (Cowan et al. 2011). The objective of this manuscript is to describe the clinical-pathological aspects of fibroblastic osteosarcoma in Didelphis albiventris.

\section{MATERIALS AND METHODS}

A wild adult male white-eared opossum (Didelphis albiventris) arrived at the zoological park of the "Universidade de Caxias do Sul" with a swollen left thoracic limb. After a general clinical examination, the animal was sent to a radiographic examination of the left thoracic limb and thorax. Since a neoplastic lesion was suspected, a fine needle aspiration (FNA) was performed. Consequently, a squash smear cytology was completed and colored with Rapid Panoptic.

The animal was euthanized due to the severe clinical conditions, the radiographic results, and the cytological analysis. During necropsy, macroscopic analysis of the viscera was performed, fragments of various organs were collected and fixed in 10\% neutral buffered formalin. All tissue fragments were processed following routine histological techniques, stained with hematoxylin and eosin (HE), and the slides were analyzed by optical microscopy.

\section{RESULTS}

At the clinical examination, the animal was identified as anorexic, dehydrated, and unsteady on walking. It was observed an increased volume and intense superficial emaciation at the left humerus-radio-ulnar joint. The radiographic evaluation of the left thoracic limb revealed an increased volume and higher radiodensity of the soft tissue around the left humerus-radio-ulnar joint. There was a loss of the trabecular shape pattern and bone lysis at the proximal ulna and radius, and at the humeral epicondyles (more intense at the lateral region). The distal humerus presented an interrupted periosteal reaction (Codman triangle), olecranon presented a pathological fracture, and soft tissues contained discrete radiopacity areas (mineralization points), all signs suggesting a bone neoplasm (Fig.1).

The sample used in the cytological evaluation presented a moderate number of cells. The majority of cells were multinucleated (osteoclasts), in addition to a smaller number of mesenchymal stem cells, manifesting either isolated or in small groups surrounded by eosinophilic extracellular matrix. Additionally, the sample was characterized by anisocytosis, anisokaryosis, and sporadic mitotic figures. The cytological findings suggested osteosarcoma diagnosis (Fig.2). All other organs did not present any macroscopic alterations.

In the necropsy, a mass measuring $15.0 \times 5.0 \times 6.0 \mathrm{~cm}$ was located around the left humerus-radio-ulnar joint. (Fig.3A). The surface cut was soft and compact, presenting white coloration, with yellowish and brownish spots, besides the bone area was easily bisected (Fig.3B). All other organs did not present any alterations during the necropsy.

The histopathological evaluation performed with the material collected from the left humerus-radio-ulnar joint showed a mesenchymal cell neoplastic proliferation, not delimited and non-encapsulated, formed by cells organized as a mantle shape, and facing different directions. These cells varied from fusiform to polygon shapes and contained eosinophilic cytoplasm, elongated nuclei, dotted chromatin, and inconspicuous nucleoli. Histopathological examination also showed moderated anisocytosis, anisokaryosis, sporadic mitotic figures, and a large number of multinucleated cells, all findings compatible with fibroblastic osteosarcoma (Fig.4). 


\section{DISCUSSION}

Osteosarcoma is the most common primary bone neoplasm diagnosed in dogs and humans (Anfinsen et al. 2011). The antemortem diagnosis of osteosarcoma in wild animals has been a challenge for veterinarians due to the scarcity of published case reports in the scientific literature and to the common accelerated growth of the disease. In order to obtain a primary bone neoplasm definitive diagnosis, one needs to associate clinical data, complementary exams, and histopathological evaluations (Garcia et al. 2007). In this report, the suggested antemortem diagnosis was performed

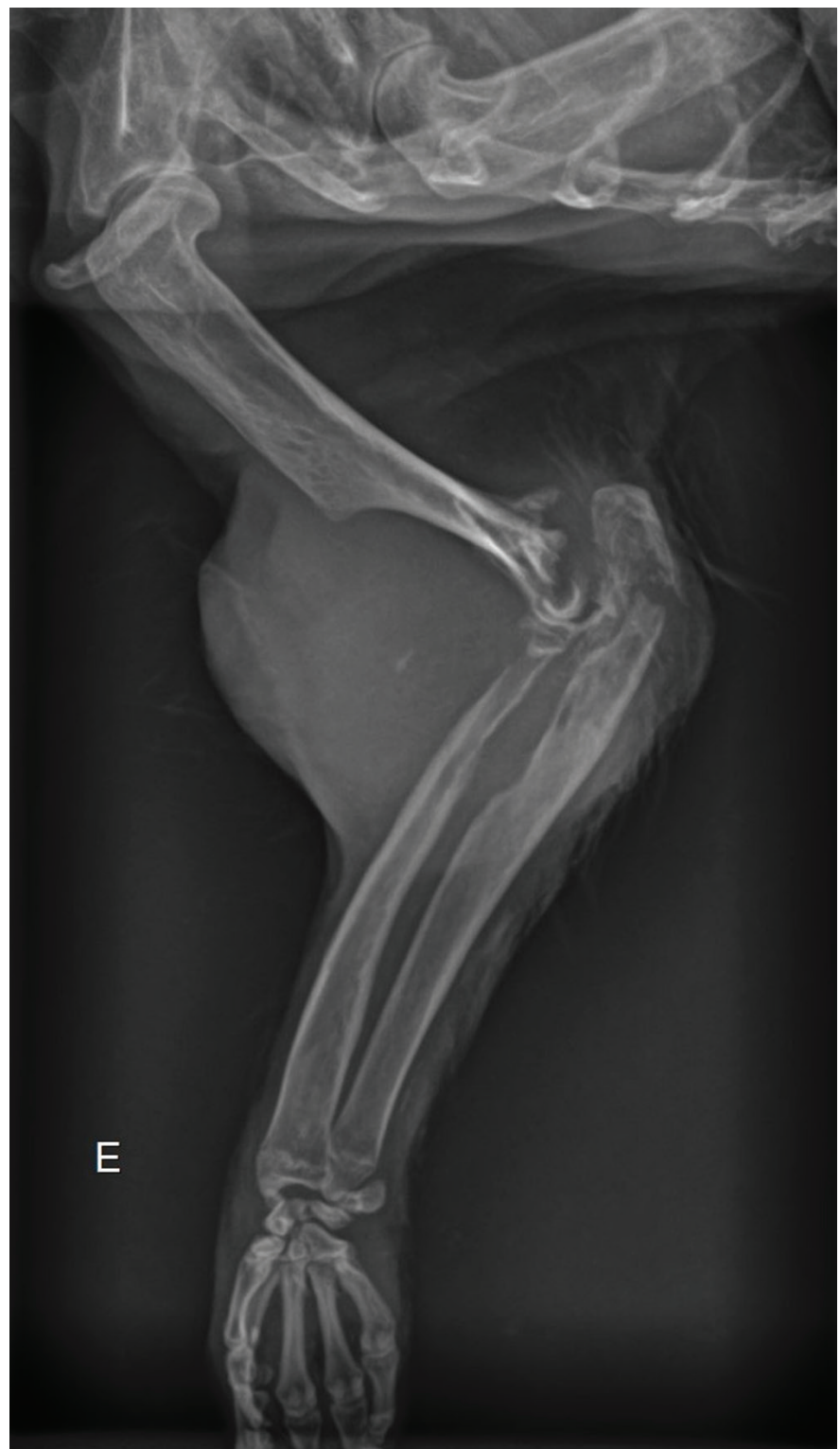

Fig.1. Simple mediolateral radiograph of left humerus-radio-ulnar joint showing increased volume and higher radiodensity in soft tissues. The trabecular shape pattern in the distal humerus is lost, in addition to bone lysis in the proximal third of ulna and radius, and humeral epicondyles. The distal humerus presents an interrupted periosteal reaction (Codman triangle), olecranon presents pathological fracture, and soft tissues contain discrete radiopacity areas (sparse mineralization). by linking clinical data, radiographic findings, and cytologic evaluations.

It is common knowledge that osteosarcoma in dogs is most commonly diagnosed during adulthood (Anfinsen et al. 2011). In this case, the white-eared opossum was clearly an adult, even though it was not possible to define its age precisely, as a consequence of being a wild animal. Osteosarcoma habitually originates from the skeletal system, affecting both appendicular and axial skeletons, though the most common is found on long bone extremities of dogs and humans (Longhi et al. 2005, Anfinsen et al. 2011, Leeper et al. 2017). In the present case, the neoplasm was located at the appendicular skeleton, in the bone structure area forming the left humerus-radio-ulnar joint, likewise suggesting an initial injury at the bone extremity.

Current searches within scientific database platforms showed no evidence of bone neoplasm descriptions in Didelphis albiventris. Pope \& Donnell (2017) observed 17 neoplasm cases in Didelphis virginiana, 14 of those categorized as malignant and 3 benign. In the same study, the neoplasm was identified as the reason for the death and euthanasia of 6 animals. The most common diagnosed neoplasm was pulmonary adenocarcinoma, followed by hemangiosarcoma, acute myeloid leukemia, undifferentiated sarcoma, trichoblastoma, mastocytoma, squamous cell carcinoma, adenoma, and osteoma.

There are a few radiographic patterns characterizing bone disorders, including mixed radiographic patterns, irregular bone contours, adjacent proliferative periosteal reaction, and adjacent soft tissue swelling (Farrow 2003). Regarding the pattern of bone destruction, the permeative pattern is considered the most aggressive, observed in cases of rapid progression tumors (Kirberger \& McEvoy 2016), as well as the irregular or interrupted periosteal reactions, which suggest a neoplasm with a severe malignity (Kealy et al. 2012). In this case report, it was possible to observe the alterations previously mentioned in the left humerus-radio-ulnar joint. These patterns support the suspected neoplasm, however, it is not possible to differentiate from other bone diseases, such as osteomyelitis, since both disorders have similar

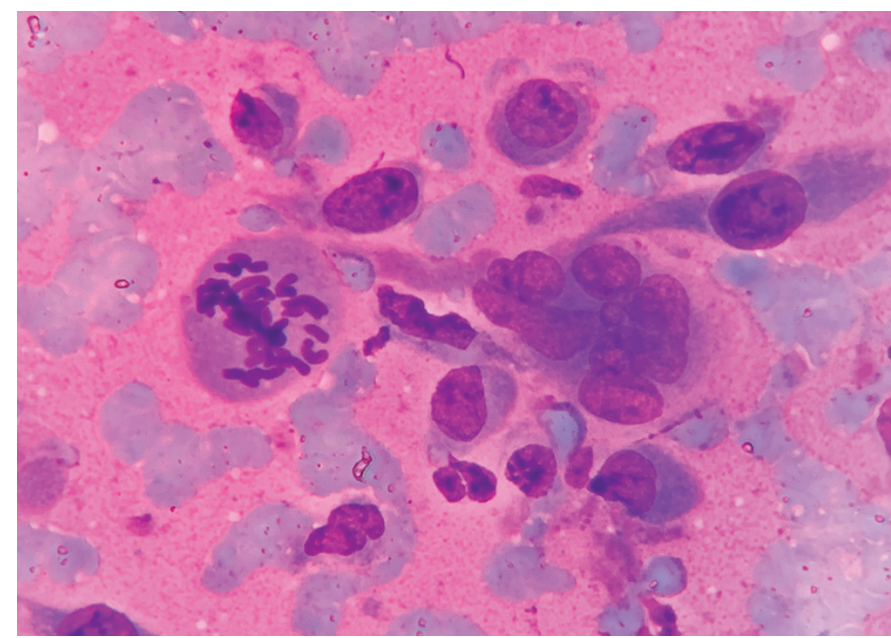

Fig.2. Cytological findings of fibroblastic osteosarcoma in Didelphis albiventris. There is a moderate quantity of mesenchymal stem cells and multinucleated (osteoclasts) cells, also characterized by anisocytosis, anisokaryosis and mitotic figures. Romanowksy, obj.10x. 


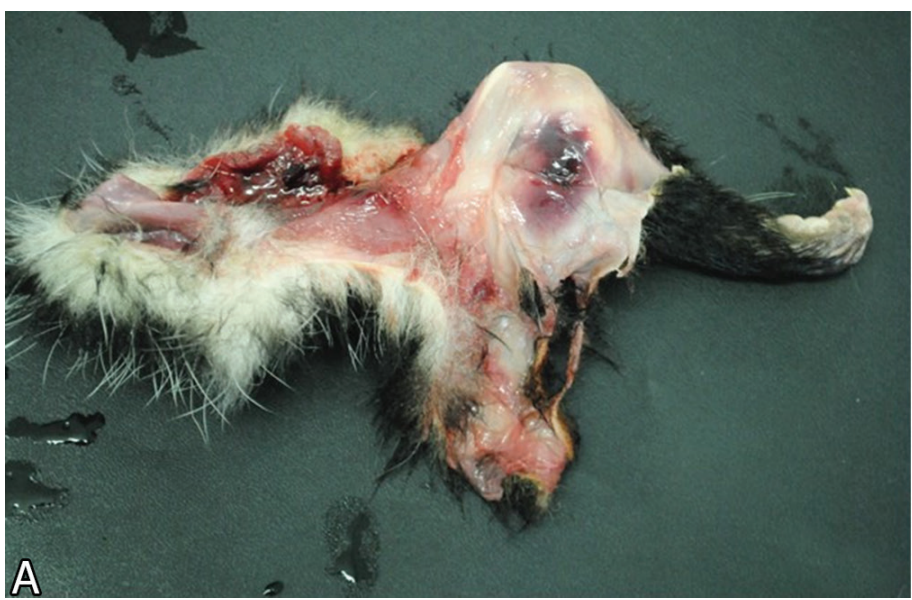

Fig.3. Macroscopic findings of osteosarcoma in Didelphis albiventris tumoral area presents white coloration with yellowish spots.

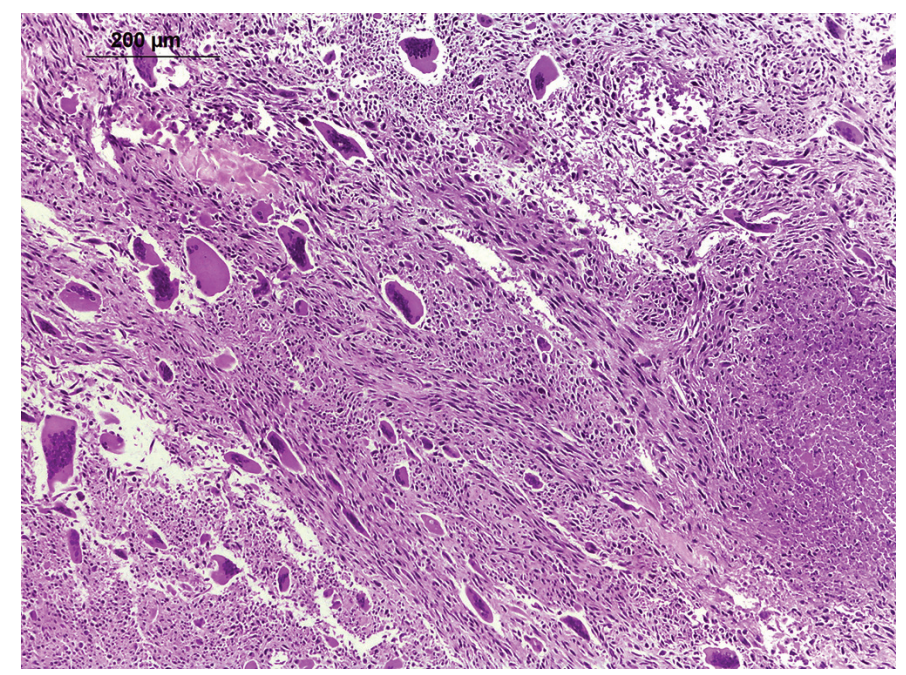

Fig.4. Fibroblastic osteosarcoma in Didelphis albiventris. Histopathological image with the proliferation of fusiform cells organized in different directions, and a high number of giant multinucleated cells. HE, bar $=200 \mu \mathrm{m}$.

radiographic alterations, and possibly happen simultaneously, which requires a cytological or histopathological evaluation, in order to obtain a definitive diagnosis (Boston et al. 2010, Kealy et al. 2012). Pathological fractures can happen due to the bone fragility found in osteosarcoma, caused by bone density reduction and necrotic areas. The occurrence of metastasis mostly occurs in the skeleton and lungs of dogs and humans, and with less frequency in the liver, kidneys, spleen, heart, and regional lymph nodes (Farrow, 2003, Boerman et al. 2012). It was not possible to observe any metastasis in either the radiographic or histopathological evaluations, in the current case report.

Osteosarcoma can be divided into three different subtypes according to the histopathological evaluation, being classified as osteoblastic, chondroblastic, and fibroblastic. The fibroblastic osteosarcoma usually begins as a lytic lesion, but approximately $50 \%$ advances to a mixed pattern when fusiform neoplastic cells increase the ability to form a bone matrix (Thompson \&

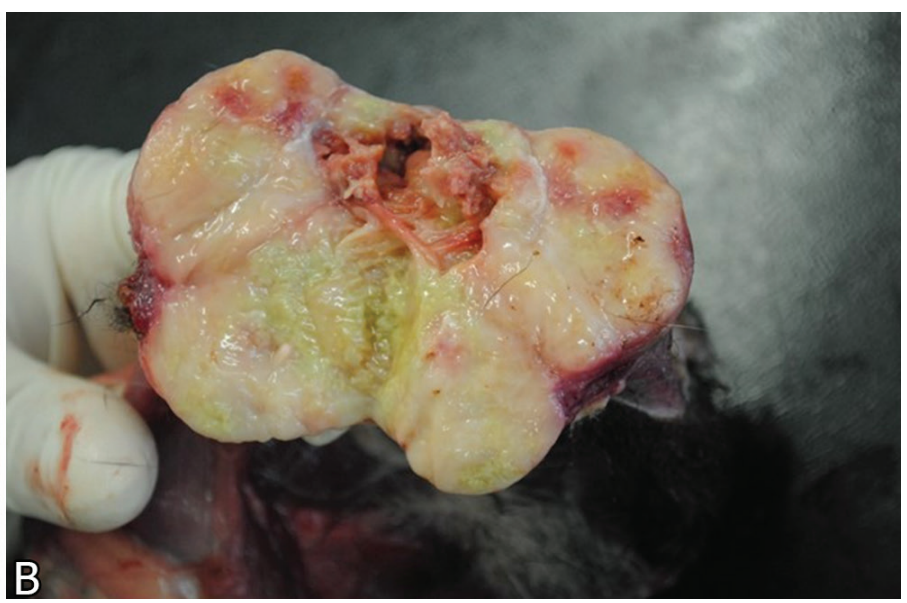

(A) Swollen left humerus-radio-ulnar joint. (B) The cut surface of the

Dittmer 2017). In this case, the histopathological evaluation showed pieces of evidence of an osteosarcoma subtype fibroblastic. Even though histopathological evaluation is considered the most accurate form of neoplasm diagnosis in animals, the cytology has seemed to be a precise form of first evaluate bone injuries, turning into a quite important tool in the clinical routine of veterinary and human medicine, in patients with suspected bone neoplasms. The cytology presents a high accuracy, especially when evaluated together with radiographic images (Thompson \& Dittmer 2017). In this particular case, the presumptive diagnosis was established using cytology in conjunction with the radiographic evaluation. Osteosarcoma cytological samples frequently present a high number of cells, but in some cases, it does not represents the lesion precisely. The material can be collected from either lytic areas or medullary cavity. In some cases, osteoclasts may be abundant, but in others, they may not be present. The quality and quantity of the osteoid matrix produced by osteoclasts may vary significantly between and within neoplasms. The osteoid production may be focal, and it is frequently marked by a chondroid area and/or fibrous tissue differentiation. In most cases, this is not a diagnosis problem, though it may be a significant challenge when cytology or histopathology samples are not available. The cytology is useful for the osteosarcoma diagnosis, but not convenient for classifying osteosarcoma withing its three different subtypes (Thompson \& Dittmer 2017).

\section{CONCLUSIONS}

There is a scarcity of case reports in the scientific literature mentioning neoplasm in free wild animals. Therefore, the description of case reports is extremely important for the knowledge of specific disorders in species with such limited information.

The association between different examinations was essential in order to obtain a specific diagnosis.

Although the observations showed were based solely on one case, this neoplasm has a clinical presentation similar to those described in other species.

Conflict of interest statement.- The authors have no competing interests. 


\section{REFERENCES}

Abreu M.C.D. 2013. Evidência de sinurbização do sariguê (Didelphis) no ecossistema urbano de Feira de Santana (BA): ocorrência e interação com os seres humanos. Master's Thesis, Universidade Estadual de Feira de Santana, Feira de Santana, BA. 114p.

Anfinsen K.P., Grotmol T., Bruland O.S. \& Jonasdottir T.J. 2011. Breed-specific incidence rates of canine primary bone tumors - A population-based survey of dogs in Norway. Can. J. Vet. Res. 75(3):209-215. <PMid:22210997>

Baker D.G., Cook L.F., Johnson E.M. \& Lamberski N. 1995. Prevalence, acquisition, and treatment of Didelphostrongylus hayesi (Nematoda: Metastrongyloidea) infection in opossums (Didelphis virginiana). J. Zoo Wildl. Med. 26(3):403-408.

Boerman I., Selvarajah G.T., Nielen M. \& Kirpensteijn J. 2012. Prognostic factors in canine appendicular osteosarcoma - a meta-analysis. BMC Vet. Res. 8:5667. <http://dx.doi.org/10.1186/1746-6148-8-56><PMid:22587466>

Boston S., Singh A., Murphy K. \& Nykamp S. 2010. Osteosarcoma masked by osteomyelitis and cellulitis in a dog. Vet. Comp. Orthop. Traumatol. 23(5):366371. <http://dx.doi.org/10.3415/VCOT-10-01-0016><PMid:20740253>

Bush J.M., Fredrickson R.L. \& Ehrhart E.J. 2007. Equine osteosarcoma: a series of 8 cases. Vet. Pathol. 44(2):247-249. <http://dx.doi.org/10.1354/ vp.44-2-247><PMid:17317809>

Churgin S.M., Steinberg H., Ravi M. \& Hartup B.K. 2013. Sternal osteosarcoma in a blue crane (Anthropoides paradiseus). J. Zoo Wildl. Med. 44(4):10751078. <http://dx.doi.org/10.1638/2012-0199R.1><PMid:24450072>

Cojean O., Langlois I., Begin-Pepin M. \& Helie P. 2018. Chondroblastic osteosarcoma of the middle ear in a guinea pig (Cavia porcellus). Can. Vet. J. 59(8):855-859. <PMid:30104775>

Costa L.P., Astua de Moraes D., Brito D., Soriano P. \& Lew D. 2015. Didelphis albiventris. The IUCN Red List of Threatened Species 2015: e.T40489A22176404. Available at <https://dx.doi.org/10.2305/IUCN. UK.2015-4.RLTS.T40489A22176404.en> Accessed on Jan. 31, 2020.

Cowan M.L., Monks D.J. \& Raidal S.R. 2011. Osteosarcoma in a woma python (Aspidites ramsayi). Aust. Vet. J. 89(12):520-523. <http://dx.doi. org/10.1111/j.1751-0813.2011.00853.x> <PMid:22103954>

Farrow C.S. 2003. Veterinary Diagnostic Imaging: the dog and cat. Mosby, St Louis, p.21-136.

Garcia S.D., Soares M.R., Silva A.R.S., Souza T.F.B., Matayoshi P.M., Luvizotto M.C.R., Ciarlini P.C. \& Ciarlini L.R.P. 2007. Descrição de um caso de osteossarcoma em ferret. Acta Sci. Vet. 35(supl.2):399-400.
Heldmann E., Anderson M.A. \& Wagner-Mann C. 2000. Feline osteosarcoma: 145 cases (1990-1995). J. Am. Anim. Hosp. Assoc. 36(6):518-521. <http://dx.doi.org/10.5326/15473317-36-6-518><PMid:11105889>

Ishikawa M., Kondo H., Onuma M., Shibuya H. \& Sato T. 2012. Osteoblastic osteosarcoma in a rabbit. Comp. Med. 62(2):124-126. <PMid:22546918>

Johnson J.G., Kim K., Serio J., Paulsen D., Rademacher N. \& Pirie G. 2014. Mandibular osteosarcoma in a nutria (Myocastor coypus). J. Zoo. Wildl. Med. 45(3):723-726. <http://dx.doi.org/10.1638/2014-0032R.1> <PMid:25314853>

Kealy J.K, McAllister H. \& Graham J.P. 2012. Diagnostic Radiology and Ultrasonography of the Dog and Cat. 5th ed. Saunders Elsevier. St Louis, p.351-446.

Kirberger R.M. \& McEvoy F.J. 2016. BSAVA Canine and Feline Musculoskeletal Imaging. 2nd ed. British Small Animal Veterinary Association, Gloucester, p.75-86.

Leeper H., Viall A., Ruaux C. \& Bracha S. 2017. Preliminary evaluation of serum total cholesterol concentrations in dogs with osteosarcoma. J. Small Anim. Pract. 58(10):562-569. <http://dx.doi.org/10.1111/jsap.12702> <PMid:28660727>

Longhi A., Pasini A., Cicognani A., Baronio F., Pellacani A., Baldini N. \& Bacci G. 2005. Height as a risk factor for osteosarcoma. J. Pediatr. Hematol. Oncol. 27(6):314-318. <http://dx.doi.org/10.1097/01.mph.0000169251.57611.8e> $<$ PMid:15956884>

Madsen T., Arnal A., Vittecoq M., Bernex F., Abadie J., Labrut S., Garcia D., Faugère D., Lemberger K., Beckmann C., Roche B., Thomas F. \& Ujvari B. 2017. Cancer prevalence and etiology in wild and captive animals, p.11-46. In: Ujvari B., Roche B. \& Thomas F. (Eds), Ecology and Evolution of Cancer, Academic Press, Massachusetts.

Mezzles M.J., Dick E.J., Owston M.A. \& Bauer C. 2015. Osteosarcoma in baboons (Papio spp.). Comp. Med. 65(2):144-149. <PMid:25926401>

Nagamine E., Matsuda K., Ishii C., Koiwa M. \& Taniyama H. 2014. Primary ischial osteosarcoma occupying the pelvic cavity in a Japanese Black cow. J. Vet. Med. Sci. 76(6):891-894. <http://dx.doi.org/10.1292/jvms.13-0491> <PMid:24492314>

Pope J.P. \& Donnell R.L. 2017. Spontaneous neoplasms in captive Virginia opossums (Didelphis virginiana): a retrospective case series (19892014) and review of the literature. J. Vet. Diagn. Invest. 29(3):331-337. <http://dx.doi.org/10.1177/1040638717704017> <PMid:28375825>

Reyes-Matute A., Mendez-Bernal A. \& Ramos-Garduno L.A. 2017. Osteosarcoma in African hedgehogs (Atelerix albiventris): five cases. J. Zoo Wildl. Med. 48(2):453-460.<http://dx.doi.org/10.1638/2016-0260R.1><PMid:28749294>

Thompson K.G. \& Dittmer K.E. 2017. Tumors of bone, p.356-424. In: Meuten D.J. (Ed.), Tumors in Domestic Animals. 5th ed. Wiley-Blackwell, Iowa. 